\title{
A numerical investigation of the effect of fiber orientation on the natural frequency of hybrid composite laminate
}

\author{
Engin Erbayrak \\ Bayburt University, Faculty of Engineering, Departmant of Mechanical Engineering, Bayburt, Turkey, (ORCID: 0000-0002-0648-8823), \\ enginerbayrak@bayburt.edu.tr
}

(1st International Conference on Applied Engineering and Natural Sciences ICAENS 2021, November 1-3, 2021)

(DOI: 10.31590 /ejosat.994844)

ATIF/REFERENCE: Erbayrak, E. (2021). A numerical investigation of the effect of fiber orientation on the natural frequency of hybrid composite laminate. European Journal of Science and Technology, (28), 188-191.

\begin{abstract}
In this study, the effect of fiber orientations on the natural frequencies of the hybrid composite laminate (HCGFRE) that is consisted of sequential stacking of plain woven carbon fiber reinforced epoxy (CFRE) and plain woven glass fiber reinforced epoxy (GFRE) fibers was investigated. A finite element approach was carried out in order to determine the natural frequencies of hybrid composite laminate. Analyzes were performed using the LS-DYNA® software. In the finite element analysis, the natural frequencies corresponding to the first three modes were determined separately for each fiber orientation $\left(0^{0}, 30^{0}, 45^{\circ}\right)$. Besides the modal analysis of hybrid composite laminates formed by sequential stacking of the same fiber orientations, the natural frequencies of hybrid composite laminates formed by stacking in different fiber orientations were also examined within the scope of the study. The same boundary conditions were applied for all fiber orientations since it is essential to study with a similar degree of freedom. In addition, the effect of the mesh sensitivity used in the finite element approach on the natural frequency is also considered. it is seen that both the change of fiber orientation and the stacking of composite plates with different fiber orientations directly affect the natural frequency values for all modes.
\end{abstract}

Keywords: Natural frequency, implicit analyses, Euler vibration, hybrid composite, fiber orientation.

\section{Hibrit kompozit laminatın lif yöneliminin doğal frekans üzerinde etkisinin sayısal bir araştırması}

Öz

Bu çalışmada, düz dokuma karbon fiber takviyeli epoksi (CFRE) ve düz dokuma cam elyaf takviyeli epoksi (GFRE) fiberlerin ardışık istiflenmesinden oluşan hibrit kompozit laminatın (HCGFRE) doğal frekansları üzerine fiber oryantasyonlarının etkisi araştırılmıştır. Hibrit kompozit laminatın doğal frekanslarını belirlemek için sonlu elemanlar yaklaşımı gerçekleştirilmiştir. Analizler LS-DYNA® yazılımı kullanılarak yapılmıştır. Sonlu elemanlar analizinde, ilk üç moda karşılık gelen doğal frekanslar, her bir fiber oryantasyonu $\left(0^{0}, 30^{0}, 45^{\circ}\right)$ için ayrı ayrı belirlenmiştir. Aynı lif yönelimlerinin ardışık istiflenmesiyle oluşturulan hibrit kompozit laminatların modal analizinin yanı sıra, farklı lif yönelimlerin de istiflenerek oluşturulan hibrit kompozit laminatların doğal frekansları çalışma kapsamında incelenmiştir. Benzer bir serbestlik derecesi ile çalışmak esas olduğundan, tüm fiber yönelimleri için aynı sınır koşulları uygulanmıştır. Ayrıca sonlu elemanlar yaklaşımında kullanılan ağ duyarlılığının doğal frekans üzerindeki etkisi de göz önünde bulundurulmuştur. Hem fiber oryantasyonunun değişmesinin hem de farklı fiber oryantasyonlarına sahip kompozit plakaların istiflenmesinin tüm modlar için doğal frekans değerlerini doğrudan etkilediği görülmektedir.

Anahtar Kelimeler: Doğal frekans, impicit analizler, Euler titreşimi, hibrit kompozit, fiber oryantasyonu. 


\section{Introduction}

Composite materials have recently gained popularity as a result of their mechanical and physical qualities, which include lightweight, high strength, and better conductivity. They've also been used in situations where corrosion resistance and convenience of manufacture are necessary. With the advancement of technology, composite materials are being refreshed. Hybrid composite technology is the first of its kind in this field. The vibrational analyses of composite materials generated from various fiber and matrix components have been determined in the literature [1-4]. However, modal analyzes of hybrid composite laminates are limited in the literature [5-6]. In particular, the vibration analysis of the hybrid composite laminate used in the study (HCGFRE) has not been found in the literature.

In this study, the effect of fiber orientations on the natural frequencies of the hybrid composite laminate (HCGFRE) that is consisted of sequential stacking of plain woven carbon fiber reinforced epoxy (CFRE) and plain woven glass fiber reinforced epoxy (GFRE) fibers was investigated. In addition, the natural frequencies of hybrid composite laminates generated by stacking in different fiber orientations were also investigated. The natural frequency results for all fiber orientation and stacking conditions of hybrid composite laminates were computed numerically.

\section{Material and Method}

\subsection{Material}

Hybrid composite laminates were formed in 8 layers using the vacuum infusion technique. Carbon and glass fibers were

used as reinforcement material, and Araldite LY 1564 epoxy adhesive was used as matrix material in the production of hybrid composite. The mechanical properties of the hybrid composite laminate to be used in finite element analysis are shown in Table 1.

\subsection{Numerical analysis}

The natural frequency values of hybrid composite laminates were determined using the LS-DYNA finite element program. In the finite element analysis, the hybrid composite plate was modeled using the $100 * 100 * 2 \mathrm{~mm}$ geometric dimensions. The mechanical properties of the hybrid composite material were assigned using Table 1. The layered composite structure was made in the finite element program by first selecting the appropriate composite material card and then creating its layers. In the material model, the MAT 22 (Composite damage) material card and the "Composite Long" card, in which the composite layers and orientation of the fibers in the layers are created, were used. The image of the material model in finite element analysis is shown in Figure 1.

Figure 1: Numerical model of hybrid composite material

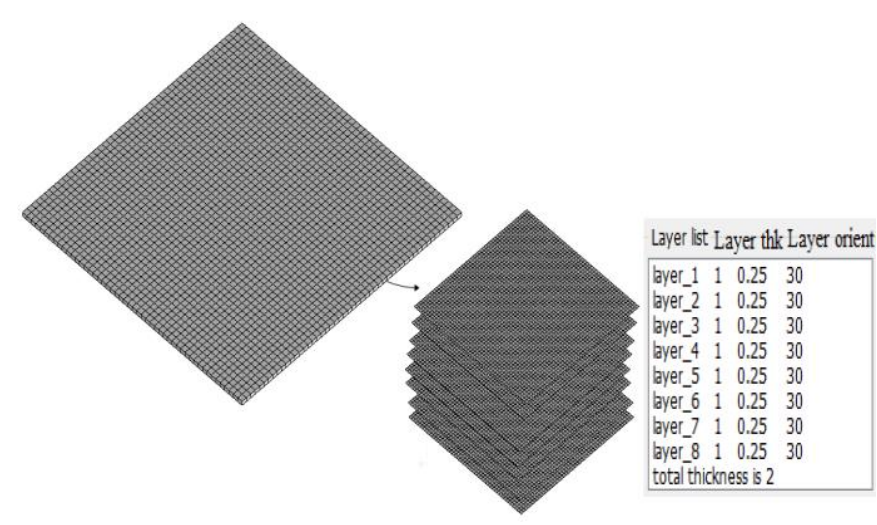

It should be stated here that a new set of Cartesian coordinates on the material must be recognized to determine the fiber orientation of composite materials. Therefore, a new coordinate has been added to the material card which the fiber orientation angles were defined. This coordinate is defined with the material axes option (AOPT). In boundary conditions, both sides of the composite laminate are attached to fixed support. It is stated here that the same boundary conditions were applied for all fiber orientations since it is essential to study with a similar degree of freedom. The Shell element with six degrees of freedom (Ux, Uy, Uz, Rotx, Roty, Rotz) was used in the modelling of the composite material. Another important point in finite element analysis is to define the appropriate element size of the model. The effect of the selected element size on the analysis results should be considered. This process is called mesh sensitivity in finite element analysis.

Table 1. Mechanical properties of HCGFRE [7].

\begin{tabular}{|l|c|}
\hline Properties & HCGFRE \\
\hline Tensile strength $(\mathrm{MPa})$ & 802.43 \\
\hline Elastisite modulus $(\mathrm{GPa})$ & 81.67 \\
\hline Elongation at break & 1.18 \\
\hline Density $\left(\mathrm{kg} / \mathrm{m}^{3}\right)$ & 1200 \\
\hline
\end{tabular}

\subsubsection{Mesh Sensitivity}

In the finite element analysis, the element size of the composite laminate was determined using mesh sensitivity. The variation of the natural frequencies of the composite laminate, which is distinguished into finite elements with different element sizes, has been investigated. The optimum element size value has been determined considering this variation. Mesh sensitivity is shown in Figure 2. 
Figure 2: Mesh sensitivity

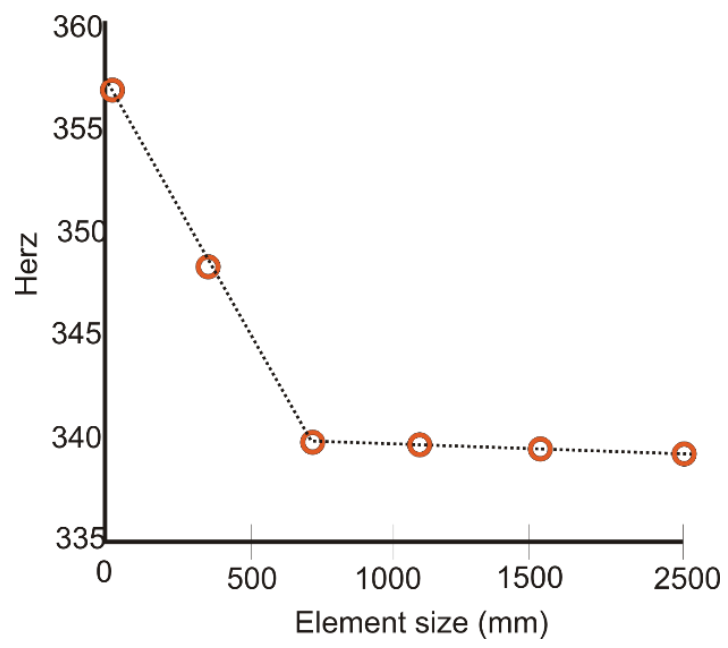

It is seen in Figure 2, the optimum element size is determined from the region where the element size change does not affect the natural frequency. The composite laminate is divided into 2500 elements and 2601 nodes.

\subsubsection{Implementation of modal analysis to hybrid composite material}

In the determination of natural frequencies in composite materials with the finite element approach, the process of taking equivalent matrices or inverses is performed at a certain time step. Meanwhile, it should be stated that the matrices mentioned are the mass and stiffness matrices. This analysis method is called implicit analysis. The natural frequencies corresponding to the first three modes of the hybrid composite laminate were determined by entering the "Implicit eigenvalue" and "Implicit general" commands in the LS-DYNA software. In addition, the time step value of the analysis is defined in the "Implicit general" command as well [8].

\section{Results and Discussion}

The effect of fiber orientations on the natural frequencies of the hybrid composite laminate (HCGFRE) was examined in this research. The natural frequencies of hybrid composite laminates made by stacking different fiber orientations were also studied. The first three mode deformation images for all fiber

It is necessary to explain how the model accuracy is ensured before evaluating the finite element analysis results. In this context, the natural frequency values of composite laminates (CFRE, GFRE) that form of the hybrid composite laminate have been found in the literature [1]. The natural frequency values were determined by creating a numerical model of the related composite laminates under similar boundary conditions with the literature. It has been observed that the obtained results converge to each other. Thus, the hybrid composite laminate was modelled after the numerical model was validated.

In the natural frequency results, it is seen that the highest and lowest natural frequency values are obtained from composite laminate with a fiber orientation of 45 degrees in all modes. Moreover, the highest natural frequency variation among the modes was also determined from composite laminate with 45-degree fiber orientation. In addition, when the results are examined in general, it is seen that both the change of fiber orientations and stacking conditions of composite laminates are shown in Figure 3.

Figure 3: The mode shapes of hybrid composite laminate

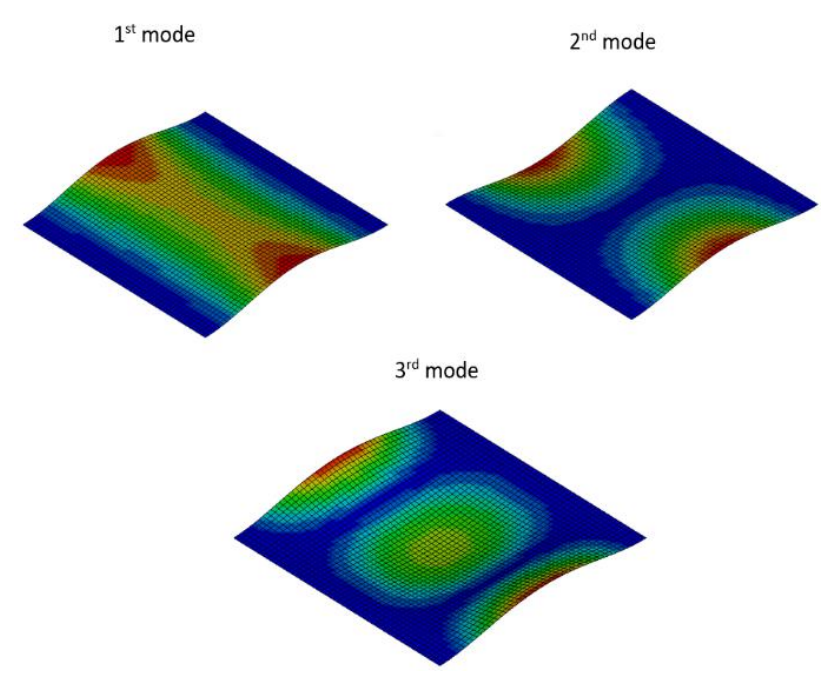

The vibration mode shapes occurring in the hybrid composite material are shown in Figure 3. The mode shapes remain the same for different fiber orientations and stacking conditions of the hybrid composite material. This is because there is no dramatic variation in the calculated natural frequency values for each mode under all conditions.

Eventually, end of the finite element analysis, the natural frequency values for the first three modes of the hybrid composite laminate for all conditions are given in Table 2.

Table 2. Natural frequencies result of HCGFRE for each mode.

\begin{tabular}{|c|c|c|c|}
\hline Conditions & $\begin{array}{c}\text { Mode I } \\
(\mathrm{Hz})\end{array}$ & $\begin{array}{c}\text { Mode } \\
\text { II }(\mathrm{Hz})\end{array}$ & $\begin{array}{c}\text { Mode III } \\
(\mathrm{Hz})\end{array}$ \\
\hline$[0]_{8}$ & 337,94 & 355,19 & 551,23 \\
\hline$[30]_{8}$ & 291,81 & 348,92 & 604,33 \\
\hline$[45]_{8}$ & 276,46 & 349,87 & 623,66 \\
\hline$[0 / 30 / 45 / 0 / 30 / 45 / 0 / 30]$ & 312,72 & 353,25 & 585,52 \\
\hline
\end{tabular}

orientation and the stacking of composite plates with different fiber orientations directly affect the natural frequency values for all modes.

\section{Conclusions and Recommendations}

The influence of fiber orientations on the natural frequencies of the hybrid composite laminate (HCGFRE) was explored in this work. The natural frequencies of hybrid composite laminates made by stacking different fiber orientations were also studied. The natural frequency findings of hybrid composite laminates were estimated numerically for all fiber orientation and stacking situations. The main conclusion is explained as follows;

- The frequency bandwidth (lowest and highest) of the composite laminate with a fiber orientation of 45 
degrees is the highest compared to the other composite laminates.

- It was observed that fiber orientation and stacking of composite plates with different fiber orientations directly affect the natural frequencies for all modes.

- It is known that defining the natural frequency variations of the composite laminate under different circumstances is crucial for determining the resonance conditions of composite laminates. It is thought that this study for HCGFRE composite laminate, which is not encountered in the literature yet, will make an important contribution to the existed literature.

\section{References}

[1] Nikhil, K.M., Indrajeet, S.B., Utkarsh, C.D., Manoharan, R., "Modal analysis of hybrid laminated composite sandwich plate," Materials Today: Proceedings.,.5, 12453$12466,2018$.

[2] Rangasamy,S., Loganathan,K., Natesan,A., "Experimental investigation and numerical analysis of the dynamic characteristics of a laminated hybrid composite bed," Polymer Composites., DOI.10.1002/pc.23555,1-7,2015.

[3] Rajkumar, D.R., Santhy, K., Padmanaban,K.P., "Influence of mechanical properties on modal analysis of natural fiber reinforced laminated composite trapezoidal plates," Journal of Natural Fibers., DOI 10.1080/15440478.2020.1724230, 1-18,2020.

[4] Bulut, M., Bozkurt, Ö.Y., Erkliğ,A., "Damping and vibration characteristics of asalt-aramid/epoxy hybrid composite laminates," Journal of Polymer Engineering., DOI.10.1515/polyeng-2015-0168, 1-8,2015.

[5] Rajeshkumar, G., Hariharan, V., "Free vibration analysis of hybrid-composite beams," in IEEE-International Conference On Advances in Engineering, Science And Management (ICAESM -2012), Tamil Nadu, India., 30 March 2012.

[6] Song, C., Fan, W., Dong, J., Zhao, Y., Lu, L., Mi, P., Xu, Y., Hou, L., Liu, T., "Modal analysis of 3D multi-axial hybrid composite with experimental and numerical methods." Applied Composite Materials DOI.10.1007/s10443-021-09962-3, 1-16,2021.

[7] Erbayrak, E., Yuncuoglu, E.U., Kahraman,Y., Gumus, B.E., "An Experimental and Numerical Determination on Low-Velocity", Iranian journal of science and technology, transactions of mechanical engineering, 45,665-681, 2021.

[8] Maker, B.N., Bensonof, D.J., "Modal methods for transient dynamic analysis in ls-dyna," in 7th International LSDYNA Users Conference, Detroit, June 2016. 